\title{
Assessment of Phosphate Solubilization and Indole Acetic Acid Production of Phosphate Solubilizing Bacteria Isolated from Acid Soils, Lampung, Indonesia
}

\author{
Muhammad Asril ${ }^{1 *}$, Yuni Lisafitri ${ }^{2}$, Ainin Niswati ${ }^{3}$, Suskandini Ratih \\ Dirmawati $^{4}$, Rismawati ${ }^{1}$, Ika Agus Rini ${ }^{1}$, Indah Oktaviani ${ }^{1}$ \\ ${ }^{I}$ Department of Biology, Institut Teknologi Sumatera, Jl. Terusan Ryacudu, Way Hui, Jati Agung, Lampung \\ Selatan, Lampung, Indonesia \\ ${ }^{2}$ Department of Environmental Engineering, Institut Teknologi Sumatera, Jl. Terusan Ryacudu, Way Hui, Jati \\ Agung, Lampung Selatan, Lampung, Indonesia \\ ${ }^{3}$ Department of Soil Science, Lampung University, Jl. Sumantri Brojonegoro I, Gedong Meneng, Bandar \\ Lampung, Lampung, Indonesia \\ ${ }^{4}$ Department of Agrotechnology, Lampung University, Jl. Sumantri Brojonegoro I, Gedong Meneng, Bandar \\ Lampung, Lampung, Indonesia \\ *Corresponding author. E-mail: m.asril@bi.itera.ac.id
}

\begin{abstract}
Phosphorus is the main macronutrient required by plants for growth and development. Phosphorus in the soil in bonds with metals such as $\mathrm{Al}$ and $\mathrm{Ca}$, especially in acid soils such as ultisols. This form of phosphate must be mineralized or dissolved using phosphate solubilizing bacteria. The ability to dissolve phosphate also correlates with the production of Indole Acetic Acid (IAA), which can increase plant growth. This study aims to assess the ability of phosphate dissolution and IAA production of three phosphate solubilizing bacteria (EF.NAP 5, EF.NAP 7, and EF.NAP 10) which have been isolated from acid soils, Lampung. The method used was the clear zone test for bacterial isolates, phosphate solubility, and measurement of IAA production during the phosphate solubility process. EF.NAP 7, EF.NAP 5 and EF.NAP 10 isolates had phosphate dissolution indexes of $0.986\left(6^{\text {th }}\right.$ day), 0.828 ( $7^{\text {th }}$ day) and 0.789 ( $3^{\text {rd }}$ day), respectively. EF.NAP 7 isolate $(392.87 \mathrm{mg} / \mathrm{L})$ was able to dissolve phosphate better than EF.NAP $10(311 \mathrm{mg} / \mathrm{L})$ and EF.NAP $5(213.37 \mathrm{mg} / \mathrm{L})$. The pH conditions on the highest phosphate solubility were EF.NAP 7 (4.94), EF.NAP 10 (4.19) and EF.NAP 5 (6.01), respectively. The three isolates of phosphate solubilizing bacteria were able to produce IAA during the phosphate dissolving process in the Liquid Pikovskaya medium without the addition of Tryptophan with IAA concentrations of EF.NAP 5 (12.5 $\mathrm{mg} / \mathrm{L})$, EF.NAP 7 (8.0 mg/L) and EF.NAP 10 (8.5 mg/L), respectively.
\end{abstract}

Keywords: IAA production, $p H$ changes, phosphate solubilize, ultisol

\section{INTRODUCTION}

Phosphorus (P) is an essential macronutrient needed by plants such as carbon and nitrogen. Plants obtain $\mathrm{P}$ elements entirely from the soil or root exudates and the results of decomposition and mineralization of organic matter [1]. The amount of $\mathrm{P}$ in the soil is strongly influenced by soil conditions.
On marginal dry land, especially ultisols, which are often found in Indonesia, which reaches 14 thousand hectares [2], constraints are often found in its utilization, namely high soil acidity levels such as in Lampung, one of which is the Institut Teknologi [3]. This situation causes low available $\mathrm{P}$ and high $\mathrm{Al}, \mathrm{Ca}$, and Fe content [4]. The low availability of $\mathrm{P}$ is due to high $\mathrm{P}$ fixation by minerals in the form of Ca-P, Al-P, 
and Fe-P so that it is difficult to be absorbed by plants. Plants use phosphate for only $10-30 \%$ of the phosphate fertilizer given so that $70-90 \%$ of phosphate fertilizer remains in the soil [1]. One way to increase the efficiency of phosphate fertilization is to use phosphate solubilizing bacteria.

Phosphate solubilizing bacteria can dissolve phosphate that is difficult to dissolve (from soil or fertilizers) to dissolve and be available in the soil so that it can be absorbed by plants [5]. The mechanism of dissolving phosphate minerals from metal bonds is the producing of organic acids and the phosphatase enzyme [4]. In addition to the ability to dissolve phosphate, the production of hormones, one of which is indole acetic acid (IAA) by bacteria, is an essential criterion as a plant growth promoter [6].

IAA is a natural auxin group phytohormone that acts as a plant growth promoter by regulating of many physiological processes such as cell division and differentiation and protein synthesis [7]. Small amounts of IAA can significantly affect plant growth and production [6]. Bacteria that can dissolve phosphate and produce IAA are a group of plant growth-promoting bacteria (PGPB). Some of these bacteria include Paenibacillus illinoisensis, Pseudomonas extremaustralis [8], P. fluorescens, Azosprillum brasilense [9]

Asril and Lisafitri [3] have succeeded in isolating various isolates from acid soils from former rubber plantations in the Institut Teknologi Sumatera area, Lampung. Some of these isolates have not been characterized in more detail regarding the potential for phosphate dissolution and IAA production which can be used as potential isolates to increase plant growth. The three isolates were EF.NAP 5, EF.NAP 7 and EF.NAP 10. Therefore, this study aimed to detect the qualitative and quantitative potential of phosphate dissolving three isolates (EF.NAP 5, EF.NAP 7, and EF. NAP 10) and its ability to produce IAA.

\section{MATERIALS AND METHODS}

This research was conducted from August to September 2020 using three collections of bacterial isolates with the code EF.NAP 5, EF.NAP 7 and EF.NAP 10, which were-isolated from the acid soils of the Institut Teknologi Sumatera

\subsection{Rejuvenation and Characterization of Selected Bacterial Isolates}

The three bacterial isolates were rejuvenated on solid Pikovskaya medium and incubated at $30{ }^{\circ} \mathrm{C}$ for
24 hours and were characterized including morphological characteristics (shape, edge, elevation, and colony color), gram staining of bacteria, and biochemical tests consisting of citrate, catalase, motility, starch hydrolysis, and sugar fermentation.

\subsection{Qualitative Estimation of Phosphate Solubilization on Solid Pikovskaya Medium}

Testing the ability of bacteria to dissolve phosphate was carried out on solid Pikovskaya media containing $10 \mathrm{~g} \mathrm{C}_{6} \mathrm{H}_{12} \mathrm{O}_{6}, 5 \mathrm{~g} \mathrm{Ca}_{3}\left(\mathrm{PO}_{4}\right)_{2}, 0.5 \mathrm{~g}$ $\left(\mathrm{NH}_{4}\right)_{2} \mathrm{SO}_{4}, 0.2 \mathrm{~g} \mathrm{KCl}, 0.1 \mathrm{~g} \mathrm{MgSO}_{4} .7 \mathrm{H}_{2} \mathrm{O}, 0.002 \mathrm{~g}$ $\mathrm{MnSO}_{4} .7 \mathrm{H}_{2} \mathrm{O}, 0.002 \mathrm{~g} \mathrm{FeSO}_{4} .7 \mathrm{H}_{2} \mathrm{O}, 0.1 \mathrm{~g} \mathrm{NaCl}, 0.5$ $\mathrm{g}$ yeast extract, $20 \mathrm{~g}$ agar are dissolved in $1000 \mathrm{ml}$ distilled water. The test was carried out by dot method using spotting on the surface of the medium and incubated at $30{ }^{\circ} \mathrm{C}$ and observed every day for 7 days [3]. The growth of $\mathrm{P}$ solubilizing bacterial colonies is characterized by the formation of a clear zone around the colony. The clear zone formed around the colony is measured and the solubility index (SI) of $\mathrm{P}$ in each colony is calculated to determine the degradation ability of bacteria to $\mathrm{P}$ with the following equation [10]:

\section{$\mathrm{SI}=\underline{\text { Clearzone diameter }- \text { Colony diameter }}$ Colony diameter}

\subsection{Quantitative Estimation of Phosphate Solubilization}

The quantitative test of the ability of bacteria to dissolve phosphate was carried out based on colorimetric assay method [11]. One loop of the isolate was inoculated in $50 \mathrm{~mL}$ of liquid Pikovskaya medium, then incubated in shaking incubator for 48 hours at $30{ }^{\circ} \mathrm{C}$ at $120 \mathrm{rpm}$. After 48 hours, $1 \%$ of the culture was inoculated into $250 \mathrm{ml}$ of liquid Pikovskaya medium, then shaking for 7 days at 30 ${ }^{0} \mathrm{C}$. Every 24 hours, $10 \mathrm{ml}$ of culture was centrifuged at $6000 \mathrm{rpm}$ for 30 minutes to separate bacterial cells from the supernatant. $1 \mathrm{ml}$ of the supernatant was reacted with color-forming reagents $(2.5 \mathrm{ml}$ sodium molybdate $2.5 \%$ and $1 \mathrm{ml}$ hydrazine sulfate $0.3 \%$ ). The supernatant and color reagent mixture were heated for 10 minutes and then cooled. After the blue color is formed, the phosphate concentration is measured by a spectrophotometer at a wavelength of $830 \mathrm{~nm}$.

\subsection{Measurement of pH Culture}

During the solubility testing of phosphate isolates, the $\mathrm{pH}$ of the culture was measured. $\mathrm{PH}$ measurement aims to determine the $\mathrm{pH}$ changes that occur during the phosphate dissolving process in 
liquid Pikovskaya medium. The change in $\mathrm{pH}$ indicates the production of organic acids during the phosphate dissolving process.

\subsection{Measurement of the Concentration of Indole Acetic Acid}

During the phosphate dissolution testing process on liquid pikovskaya medium, IAA levels were also measured. Direct measurement of IAA levels uses the supernatant used in the phosphate solubility test. The aim is to detect the ability to produce IAA during the phosphate dissolving process simultaneously without the addition of tryptophan as a precursor. The supernatant obtained in the phosphate solubility test was reacted with $4 \mathrm{ml}$ of Salkowski's reagent $\left(150 \mathrm{ml} \mathrm{H}_{2} \mathrm{SO}_{4}, 250 \mathrm{ml}\right.$ aquades, $\left.7.5 \mathrm{ml} 0.5 \mathrm{M} \mathrm{FeCl}_{3} \cdot 6 \mathrm{H}_{2} \mathrm{O}\right)$ incubated for 30 minutes in a dark room (Pattern \& Glick, 2002). Then the IAA concentration was measured using a spectrophotometer at a wavelength of $535 \mathrm{~nm}$ [12].
The IAA concentration is measured using the IAA standard curve.

\section{RESULT AND DISCUSSION}

The three phosphate solubilizing isolates had less variable characteristics. EF.NAP 5 and EF.NAP 10 isolates have a circular, entire edge, raised elevation, and white shape. While the EF.NAP 7 isolate has a circular shape, undulating edges, convex elevation, and is white (Table 1). The results of gram staining indicated showed that the EF.NAP 5 and EF.NAP 7 isolates were gram-positive bacteria in the form of coccus. Meanwhile, EF.NAP 10 is gram-negative in the form of coccus. Based on the biochemical test, the three isolates also had non-varied characters (Table 2). The three isolates were able to hydrolyze starch, were aerobic, ferment glucose, and produce $\mathrm{H}_{2} \mathrm{~S}$ in the form of black deposits. The three isolates also can use citrate as a carbon source.

Table 1. Characterization of phosphate solubilizing isolates

\begin{tabular}{|c|c|c|c|c|c|c|}
\hline \multirow{2}{*}{ Isolate Code } & \multicolumn{4}{|c|}{ Morphology of Colony } & \multirow{2}{*}{ Gram } & \multirow{2}{*}{$\begin{array}{c}\text { Morphology of } \\
\text { cell }\end{array}$} \\
\hline & Shape & Edge & Elevation & Colour & & \\
\hline EF.NAP 5 & Circular & Entire & Raised & White & Positive & Coccus \\
\hline EF.NAP 7 & Circular & Undulate & Convex & White & Positive & Coccus \\
\hline EF.NAP 10 & Circular & Entire & Raised & White & Negative & Coccus \\
\hline
\end{tabular}

Table 2. Biochemical testing of phosphate solubilizing isolates

\begin{tabular}{ccccccccc}
\hline Isolate Code & $\begin{array}{c}\text { Starch } \\
\text { Hydrolysis }\end{array}$ & Citrat & Catalase & Motility & \multicolumn{4}{c}{ TSI Test } \\
\cline { 6 - 8 } EF.NAP 5 & + & + & + & - & Plucose & Sucrose & Lactose & $\mathbf{H}_{2}$ S \\
EF.NAP 7 & + & + & + & - & Positive & Coccus & - & + \\
EF.NAP 10 & + & + & + & - & Negative & Coccus & - & + \\
\hline
\end{tabular}

Based on the phosphate dissolution test on solid Pikovskaya medium, the three bacterial isolates were able to dissolve Ca3PO4, indicated by forming of clear zone around the colony. After 7 days of incubation, various clear zones were formed. EF.NAP 7 isolate had the highest SI than other isolates, namely 0.986 on the $6^{\text {th }}$ day of incubation. Meanwhile, EF.NAP 5 has an SI of 0.828 on the 7th day and EF. The NAP 10 was 0.789 on the 3rd day of incubation (Fig. 1).
The formation of the clear zone indicates the activity of the phosphate dissolving and acid formation by bacteria. The formation of a clear zone around the colony indicates that the isolate can produce organic acids, which can bind with $\mathrm{Ca}$ ions to form $\mathrm{Ca}_{3}\left(\mathrm{PO}_{4}\right)_{2}$ compounds in Pikovskaya medium and free $\mathrm{H}_{2} \mathrm{PO}_{4}$ ions to form clearer colored areas [13]. The change in the turbidity of the medium around the colony becomes clear, due to a decrease in $\mathrm{pH}$ in the medium [14]. 


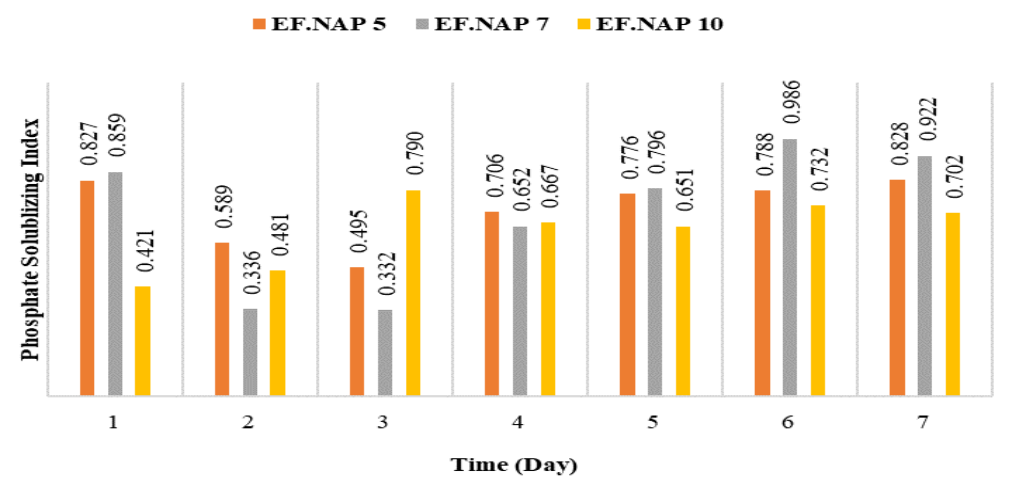

Figure 1. Phosphate Solubilizing Index of Isolates of three isolates for 7 days observation

Various bacteria have been reported to have various SI phosphates, including Pseudomonas GSP 01 and GSP 13 of 0.885 and 0.639 , respectively [3], Pseudomonas psychrotolerans GPA2.1 of 0.304 , Stenotrophomonas maltophilia GPA2.2 of 0.263 and Bacillus megaterium GPC1 .7 of 0.278 [15]. The ability of bacterial phosphate dissolving can be seen from the phosphate dissolution index, the higher the SI value, the higher the phosphate dissolving ability of the isolates. Several factors that influence the phosphate dissolution index in solid media include (a) microbial growth rate, (2) microbial ability to dissolve phosphate, (3) concentration of phosphate source in a medium that is not completely dissolved, (4) thickness of agar. The clear zone on solid media cannot show each bacteria's ability to dissolve the amount of dissolved phosphate. This is because the clear zone formed is an early sign of phosphate dissolution by bacteria. Selvi et al. [16] also reported that the ability of bacteria to dissolve phosphate qualitatively in solid pikovskaya medium would be different quantitatively in liquid pikovskaya medium.

Based on the quantitative solubility of phosphate, the three isolates had high activity. EF.NAP 7 isolates had the highest phosphate dissolving activity of $392.87 \mathrm{mg} / \mathrm{L}$ compared to EF.NAP 10 and EF.NAP 5 isolates were $311 \mathrm{mg} / \mathrm{L}$ and $213.37 \mathrm{mg} / \mathrm{L}$, respectively (Fig. 2). It can be seen that there are differences in activity qualitatively and quantitatively in isolates EF.NAP 5 and EF.NAP 7. Qualitatively, it isolates EF.NAP 5 has a higher activity than EF.NAP 10. However, quantitatively EF.NAP 10 has activity higher than EF.NAP 5. The same results were reported by Fitriyanti et al. [15] on Bacillus megaterium GPC1.7 which has a quantitative phosphate dissolution index of 0.278 but produces a quantitative dissolving phosphate of $450 \mathrm{mg} / \mathrm{L}$.

This confirms that high phosphate dissolution in solid media is not necessarily positively correlated with high phosphate dissolution quantitatively.
Several reports show the same conditions in bacteria in these phosphates' solubilizing activity [12;17]. In the process of dissolving phosphate quantitatively, the enzyme phosphatase has a very important role. Phosphatase enzymes can to catalyze enzymatic hydrolytic mineralization reactions by releasing undissolved phosphate to dissolve it [18] to bind with dye reagents in the form of blue.

The quantitative test of phosphate dissolution from the isolates showed that the maximum $\mathrm{P}$ dissolution was observed on third day incubation for the EF.NAP 10 bacterial isolates with a concentration of and $311 \mathrm{mg} / \mathrm{L}$. While the EF.NAP 7 isolates had the highest activity on $4^{\text {th }}$ day with a $\mathrm{P}$ dissolving concentration of $392.87 \mathrm{mg} / \mathrm{L}$. Another isolate, EF.NAP 5, had the highest activity on $7^{\text {th }}$ day with a concentration of $213.37 \mathrm{mg} / \mathrm{L}$. The solubility of $\mathrm{P}$ isolates fluctuated during the $7^{\text {th }}$ day of observation. Changing dissolved $\mathrm{P}$ concentrations in liquid culture can occur due to the deposition of $\mathrm{P}$ from organic metabolites or the formation of organophosphate compounds with organic acid secretion [19]. These organic acids can then be used as a source of energy or a source of nutrition.

The change in concentration is related to the uptake of dissolved $\mathrm{P}$ as a source of energy or nutrition for bacterial cells. Suppose the dissolved $\mathrm{P}$ uptake rate is higher than the $\mathrm{P}$ dissolution rate by bacteria. In that case, there will be a decrease in the $\mathrm{P}$ concentration in the medium. However, when the level of dissolved P uptake decreases, the amount of dissolved $\mathrm{P}$ in the medium increases again [20]. Besides, the organic acids secreted by bacteria contribute to the dissolution of $\mathrm{P}$. Three factors play a role in this process, namely $\mathrm{pH}$, type of organic acid, and environmental acidity feedback [21]. Bacteria will release organic acids during the phosphate dissolving process, thus lowering the medium's $\mathrm{pH}$, which indicates the dissolution of phosphate by bacteria so that the dissolving process runs well [22]. 


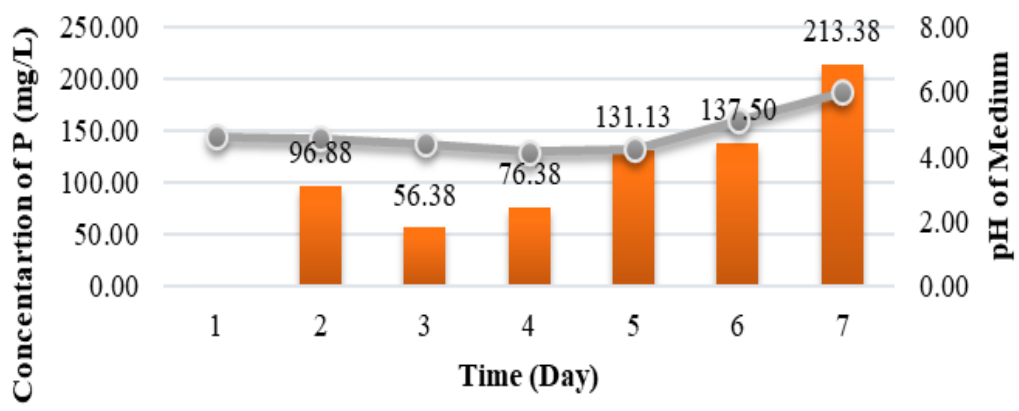

Concentration of $\mathrm{P} \quad=0 \mathrm{pH}$

A

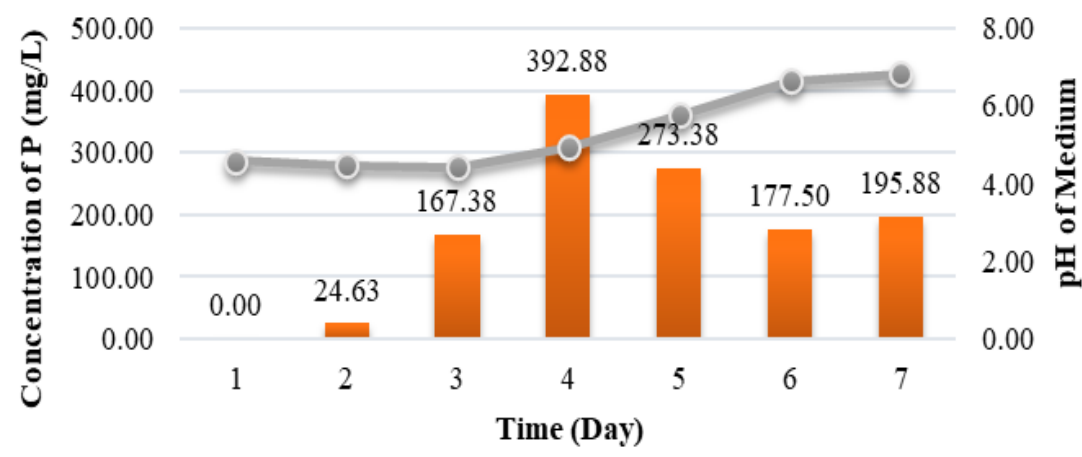

Concentration of $\mathrm{P} \quad=0 \mathrm{pH}$

B

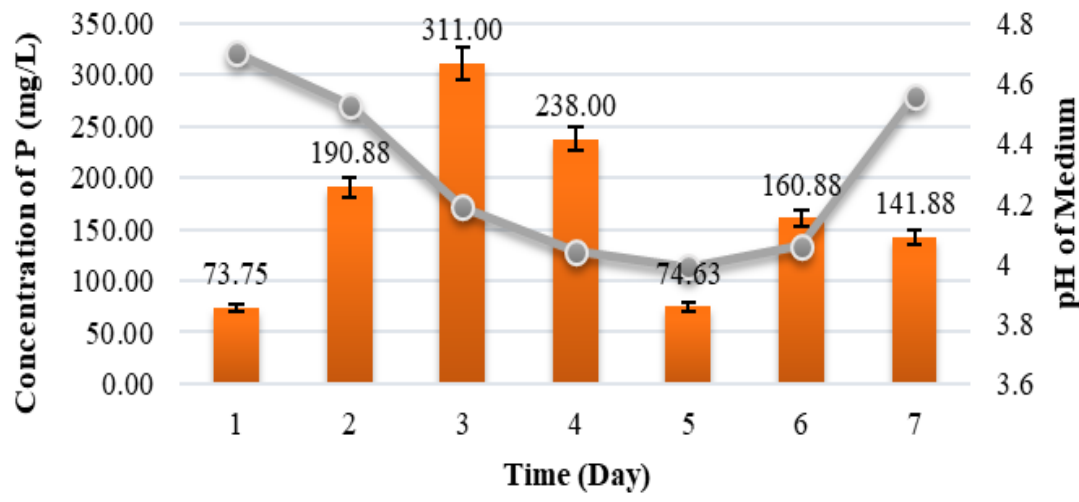

Concentration of $\mathrm{P} \quad=0 \mathrm{pH}$

C

Figure 2. Phosphate solubility concentration and $\mathrm{pH}$ of medium of 3 isolates EF.NAP 5 (A), EF.NAP 7 (B) and EF.NAP 10 at $30^{\circ} \mathrm{C}$ for 7 days observation. 
In the $\mathrm{P}$ dissolving process, microorganisms can decrease the $\mathrm{pH}$ in the growth medium by producing organic acids or protons that cause the dissolution of the mineral-phosphate complex through the exchange of $\mathrm{PO}_{4}{ }^{2-}$ anions with acid anions or chelation of phosphate-binding mineral ions.

During the phosphate dissolving process, it was seen the $\mathrm{pH}$ of the medium changed with a different pattern. EF.NAP 5 and EF.NAP 7 isolates had the same $\mathrm{pH}$ change, which increased with the length of the incubation period. While the EF.NAP 10 isolates decreased in $\mathrm{pH}$ and the length of the incubation period and increased again after six days of incubation. Naturally, during the phosphate dissolving process, the bacteria will produce organic acids, thereby lowering the $\mathrm{pH}$ in the medium, indicating that the dissolving process is complete [22] as shown in isolates EF.NAP 10. However, changes in the $\mathrm{pH}$ of the medium are as reported, not applicable to isolates EF.NAP 5 and EF.NAP 7. Marra et al. [23] reported no correlation between the decrease in $\mathrm{pH}$ and the value of phosphate dissolving by bacteria. Pseudomonas sp. able to dissolve 31.0 $\mathrm{mg} / \mathrm{L}$ of phosphate without changing the $\mathrm{pH}$ of medium [24].

The factor of high and low phosphate dissolution by bacteria is not only determined by a decreasing $\mathrm{pH}$ in the medium. There are other factors, namely the production of exopolysaccharides by bacteria [24]. Regardless of the increase and decrease in the $\mathrm{pH}$ of the medium during the phosphate dissolving process. The results of this study indicated that the highest phosphate dissolving activity in EF.NAP 10 and EF.NAP 7 isolates were in the $\mathrm{pH}$ range 4.19-4.94 (acid category). This $\mathrm{pH}$ is not too different from the soil sample used as a source of isolates, 4.09 [3; 25]. While the EF.NAP 5 isolates had the highest phosphate dissolving activity at $\mathrm{pH}$ 6.01. This condition is like the bacteria Chryseobacterium sp. (CC-BC05), which can dissolve phosphate at $\mathrm{pH} 6.0$ [26]. The ability of EF.NAP 7, EF.NAP 10 and EF.NAP 5 isolates to dissolve phosphate quantitatively were categorized as potential phosphate solubilizing isolates. This is because various phosphate solubilizing bacteria reports can only dissolve $24.808 \mathrm{mg} / \mathrm{L}$ and $22.622 \mathrm{mg} / \mathrm{L}$ phosphate produced by bacteria originating from peat soils [1].

Apart from being phosphate solubilization, another potential for bacteria to promote plant growth is IAA production. During the phosphate dissolving process in liquid Pikovskaya medium, the three isolates were detected to have the ability to produce

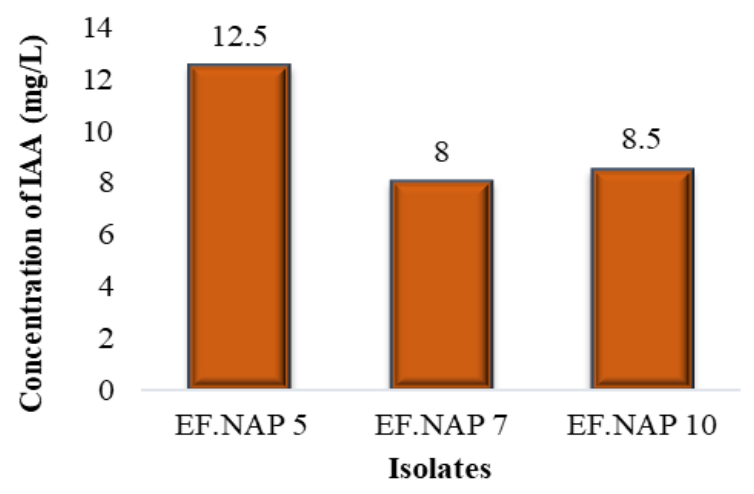

Figure 3. The highest Indole Acetic Acid concentration of three phosphate solubilizing bacteria during estimation phosphate solublization on liquid Pikovskaya medium

IAA. The highest IAA production was produced by isolates EF.NAP 5 at $12.5 \mathrm{mg} / \mathrm{L}$, followed by EF.NAP 10 at $8.5 \mathrm{mg} / \mathrm{L}$ and EF.NAP 7 at $8.0 \mathrm{mg} / \mathrm{L}$ (Fig. 3).

Several factors influence IAA production by bacteria, one of which is the type of isolate [27]. One of the types of bacteria known as IAA producers is Bacillus sp. These bacteria are capable of producing IAA of 28.10- $66.20 \mathrm{mg} / \mathrm{L}$ [28]. Apart from the type of isolate, IAA levels were also influenced by tryptophan in the growth medium. Tryptophan is a precursor in the formation of IAA. Microbes use tryptophan as a nitrogen source to produce IAA. Most of the bacteria are highly dependent on the presence of tryptophan, and both are obtained from root exudates and growth media called IAA tryptophan dependent.

In this study, the media used did not contain tryptophan. However, the three types of isolates were able to produce IAA even in small amounts. These bacteria produce IAA without tryptophan using the independent tryptophan pathway. This independent tryptophan pathway has been widely used by bacteria, one of which is Paenibacillus sp. These bacteria can produce IAA of 1.4-1.9 $\mu \mathrm{g} / \mathrm{ml}$ [29], Bacillus sp. amounting to $4,139 \mathrm{mg} / \mathrm{L}$, and Escherichia coli of $4.20 \mathrm{mg} / \mathrm{L}$ [27]. These bacteria's ability to produce IAA in the absence of tryptophan by using other aromatic amino acids as a substrate to produce IAA such as phenylalanine, tyrosine and even aspartate [30]. This amino acid can be obtained from the citric acid cycle (provider of precursors for amino acid biosynthesis) during the process of phosphate dissolving by bacteria. 


\section{CONCLUSION}

Three isolates of bacteria namely EF.NAP 5, EF.NAP 7 and EF.NAP 10 can dissolve phosphate qualitatively in solid Pikovskaya medium with Phosphate Dissolution Index of 0.986 (6 ${ }^{\text {th }}$ day), 0.828 ( $7^{\text {th }}$ day), and 0.789 ( $3^{\text {rd }}$ day). EF.NAP 7 isolates could dissolve phosphate quantitatively at 392.87 $\mathrm{mg} / \mathrm{L}$ on day $4^{\text {th }}$ compared to EF.NAP 10 isolates, respectively $311 \mathrm{mg} / \mathrm{L}$ (day $3^{\text {rd }}$ ) and $213.37 \mathrm{mg} / \mathrm{L}$ (day $7^{\text {th }}$ ). The maximum phosphate dissolution of these three bacteria is in the $\mathrm{pH}$ range $4.19-6.01$. Besides, these three isolates can produce IAA without using tryptophan for EF.NAP 5 (12.5 mg/L), EF.NAP 7 (8.0 mg/L) and EF.NAP 10 (8.5 mg/L), respectively.

\section{ACKNOWLEDGMENT}

Thank you to the Ministry of Research and Technology and National Agency for research funding through a collaborative research scheme between universities with a contract number 009/SP2H/LT/DRPM/2020.

\section{REFERENCES}

[1] E.D. Larasati, M.G.I. Rukmi, E. Kusdiyantini, C.B. Ginting, Isolasi dan identifikasi bakteri pelarut fosfat dari tanah gambut, Bioma 20(1) (2018)

1-8.

DOI: https://doi.org/10.14710/bioma.20.1.1-8. [In Bahasa Indonesia]

[2] D.N. Cakrabawa, L. Hakim, R. Gultom, Statistics of Agricultural Land, Center for Agricultural Data and Information System Secretariate General-Ministry of Agriculture, 2003.

[3] M. Asril, Y. Lisafitri, Isolasi bakteri pelarut fosfat genus Pseudomonas dari tanah masam bekas areal perkebunan karet di kawasan Institut Teknologi Sumatera, Jurnal Teknologi Lingkungan 21(1) (2020) 40-48. DOI: https://doi.org/10.29122/jtl.v21i1.3743. [In Bahasa Indonesia]

[4] M.R. Setiawati, E. Pranoto, Comparison of some exogeneous solublizing phosphate bacteria on Andisol as Indonesia dominant native tea soil, Jurnal Penelitian Teh dan Kina 18(2) (2015) 159-164. DOI: https://doi.org/10.22302/pptk.jur.jptk.v18i2.7 $\underline{8}$

[5] L.N. Alfiah, D. Zul, Nelvia, Pengaruh inokulasi campuran isolat bakteri pelarut fosfat indigenous Riau terhadap pertumbuhan dan produksi tanaman kedelai (Glycine max L. Merr), Jurnal Agroteknologi 7(1) (2016) 7-14. DOI: http://dx.doi.org/10.24014/ja.v7i1.2243. [In Bahasa Indonesia]

[6] I. Istiqomah, L.Q. Aini, A.L. Abadi, Kemampuan Bacillus subtilis dan Pseudomonas fluorescens dalam melarutkan fosfat dan memproduksi IAA (Indole Acetic Acid) untuk meningkatkan pertumbuhan tanaman tomat. Buana Science 17(1) (2017) 75-84. DOI: https://doi.org/10.33366/bs.v17i1.580. [In Bahasa Indonesia]

[7] E.E. Idris, D.J. Iglesias, M. Talon, R. Borriss, Tryptophan-dependent production of indole-3acetic acid (IAA) affects level of plant growth promotion by Bacillus amyloliquefaciens FZB42, Molecular Plant Microbe Interaction 20(6) (2007) 619-626. DOI: 10.1094/MPMI-20$\underline{6-0619}$

[8] G.R. Kuduyarova, L.B. Vysotskaya, T.N. Arkhipova, L.Y. Kuzmina, N.F. Galimsyanova, L.V. Sidorova, I. M. Gabbasova, A.I. Melentiev, S.Y. Veseleov, Effect of auxin producing and phosphate solublizing bacteria on mobility of soil phosphorus, growth rate, and $\mathrm{P}$ acquisition by wheat plants, Acta Physiologiae Plantarum 39(253) (2017) 1-8. DOI: https://doi.org/10.1007/s11738-017-2556-9

[9] I.M. Kadmiri, L. Chaouqui, S.E. Azaroual, B. Sijilmassi, K. Yaakoubi, I. Wahby, Phosphatesolubilizing and auxin-producing rhizobacteria promotes plant growth under saline conditions, Arabian Journal for Science and Engineering 43(7) (2018) 3403-3415. DOI: https://doi.org/10.1007/s13369-017-3042-9

[10] E. Mursyida, N.R. Mubarik, A. Tjahjoleksono, Selection and identification of phosphatepotassium solubilizing bacteria from the area around the limestone mining in Cirebon quarry, Research Journal of Microbiology 10(6) (2015) 270-279. DOI: $\underline{10.3923 / \mathrm{jm} .2015 .270 .279}$

[11] T.M. Lynn, H.S. Win, E.P. Kyaw, Z.K. Latt, S.S. Yu, Characterization of phosphate solubilizing and potassium decomposing strains and study on their effects on tomato cultivation, International Journal of Innovation and Applied Studies 3(4) (2013) 959-966.

[12] T. Sharma, N. Rai, Isolation of plant hormone (Indole-3-Acetic Acid) producing rhizobacteria and study on their effects on tomato (Lycopersicum esculentum) seedling, International Journal of PharmTech Research. 7(1) (2015) 99-107. 
[13] A. Sagervansh, P. Kumari, A.N. And, A. Kumar, Media optimization for inorganic phosphate solubilizing bacteria isolate from Anand agriculture soil, International Journal of Life Science \& Pharma Research. 2(3) (2012) 245-255.

[14] D. Paul, S.N. Sinha, Isolation and characterization of phosphate solubilizing bacterium Pseudomonas aeruginosa KUPSB12 with antibacterial potential from river Ganga, India, Annals of Agrarian Science 15(1) (2017) 130-136.

DOI: https://doi.org/10.1016/j.aasci.2016.10.001

[15] D. Fitriyanti, N.R. Mubarik, A. Tjahjoleksono, Characterization of phosphate solubilizing bacteria and nitrogen fixing bacteria from limestone mining region, Malaysian Journal of Microbiology 13(3) (2017) 147-155. DOI: http://dx.doi.org/10.21161/mjm.95016

[16] K.B. Selvi, J.J.A. Paul, V. Vijaya, K. Saraswathi, Analyzing the efficacy of phosphate solubilizing microorganisms by enrichment culture techniques, Biochemistry \& Molecular Biology Journal 3(1) (2017) 1-7. DOI: 10.21767/2471-8084.100029

[17] I. Reyes, A. Valery, Z. Valduz, Phosphatesolubilizing microorganisms isolated from rhizosperic and bulk soils of colonizer plants at an abandoned rock phosphate mine, Plant and Soil 287(1-2) (2006) 69-75. DOI: https://doi.org/10.1007/s11104-006-9061-z

[18] A. Ranjan, M.R. Mahalakshmi, M. Sridevi, Isolation and characterization of phosphatesolubilizing bacteria from different crop fields of Salem, Tamil Nadu, India, International Journal of Nutrition, Pharmacology, Neurogical Diseases 3(1) (2013) 29-33.

[19] B. Lugtenberg, F. Kamilova, Plant-growthpromoting rhizobacteria, Annual Review of Microbiology 63(1) 541-556. DOI: $\underline{10.1146 / a n n u r e v . m i c r o .62 .081307 .162918}$

[20] H. Rodriguez, R. Fraga, Phosphate solubilizing bacteria and their role in plant growth promotion, Biotechnology Advances 17(4) (1999) 319-339. DOI: https://doi.org/10.1016/S0734-9750(99)00014-2

[21] Z. Li, T. Dai, L. Dai, F. Wang, J. Tao, S. Meng, Y. Hu, S. Wang, S. Hu, A study of organic acid production in contrasts between two phosphate solublizing fungi: Penicillium oxalicum and Aspergillus niger, Scientific Reports 6(25313) 25313 $1-8$

DOI:
[22] H. Singh, M.S. Reddy, M. Effect of inoculation with phosphate solubilizing fungus on growth and nutrient uptake of wheat and maize plants fertilized with rock phosphate in alkaline soils, European Journal of Soil Biology 47(1) (2011) 30-34.

DOI: https://doi.org/10.1016/j.ejsobi.2010.10.005

[23] L.M. Marra, S.M. de Oliveira-Longatti, C.R.F.S Soares, J.M. de Lima, F.L. Olivares, F.M.S. Mor`eira, Initial $\mathrm{pH}$ of medium affects organic acids production but do not affect phosphate solubilization, Brazilian Journal of Microbiology 46(2) (2015) 367-375. DOI: https://doi.org/10.1590/S1517$\underline{838246246220131102}$

[24] P. Hariprasad, S.R. Niranjana, Isolation and characterization of phosphate solubilizing rhizobacteria to improve plant health of tomato, Plant Soil 316(1) 13-24. DOI: https://doi.org/10.1007/s11104-008-9754-6

[25] M. Asril, Y. Lisafitri, Amount of soil phosphate solubilizing bacteria in the reservoir of itera and its environmental conditions, in: Proceeding of International Conference on Science, Infrastructure Technology and Regional Development, IOP Conference Series: Earth and Environmental Science, IOP Publishing Ltd, Bristol, England, 2019, 258 (012026), pp. 1-7. DOI: $\quad$ https://doi.org/10.1088/17551315/258/1/012026

[26] Y.P. Chen, P.D. Rekha, A.B. Arun, F.T. Shen, W.A. Lai, C.C. Young, Phosphate solubilizing bacteria from subtropical and their tricalcium phosphate solubilizing ability, Applied Soil Ecology 34(1) (2006) 33-41. DOI: https://doi.org/10.1016/j.apsoil.2005.12.002

[27] M. Asril, Uji Potensi Bacillus sp. and Escherichia coli dalam menghasilkan Indole Acetic Acid (IAA) tanpa menggunakan triptofan pada media pertumbuhan, Journal of Science and Applicative Technology 1(2) (2017) 82-86. DOI: https://doi.org/10.35472/281434. [In Bahasa Indonesia]

[28] K.M. Lwin, K. M.M. Myint, T. Tar W.Z.M. Aung, Isolation of plant hormone (indole-3acetic acid-IAA) producing rhizobacteria and study on their effects on maize seedling, Engineering Journal 16(5) (2012) 137-144. DOI: https://doi.org/10.4186/ej.2012.16.5.137

[29] J.J. Acuna, M.A. Jorquera, O.A. Martinez, D. Menezes-Blackburn, M.T. Fernandez, P. Marschner, R. Greiner, M.L. Mora, Indole acetic acid and phytase activity produced by rhizosphere Bacilli as effected by $\mathrm{pH}$ and 
metals, Journal of Soil Science and Plant Nutrition 11(3) (2011) 1-12. DOI: https://dx.doi.org/10.4067/S071895162011000300001
[30] A.G. Moat, J.W. Foster, M.P. Spector, Microbial Physiology, Wiley-Liss Inc., 2002. 